\title{
STUDI KELAYAKAN PENDIRIAN USAHA PENJUALAN DAN PENGGILINGAN DAGING SAPI
}

\author{
Meita Sondang Riski \\ Sekolah Tinggi Ilmu Ekonomi Nusantara Sangatta \\ Email : meitasondang@yahoo.com
}

\begin{abstract}
Abstrak
Tujuan dari penelitian ini adalah menganalisis kelayakan pendirian usaha jasa penjualan dan penggilingan daging sapi di Sangatta dilihat dari keuntungan finansial. Beberapa kriteria investasi yang digunakan untuk menentukan diterima atau tidaknya sesuatu usulan usaha adalah Net Present Value (NPV), IRR (Internal Rate of Return), BEP (Break Even Point). Hasil penelitian di dapat NPV (Net Present Value) yang dapat dicapai selama lima tahun adalah sebesar Rp. 7.181.879.315,- Keuntungan ini sangat baik dengan memberikan nilai positif yang cukup tinggi, sehingga usaha proyek ini baik dan layak untuk dikerjakan. IRR sebesar 21,30\% dan Net B/C = 50,2. Oleh karena nilai Net B/C> 1, maka memberikan arti bahwa gagasan/usaha proyek tersebut layak untuk dikerjakan. Studi kelayakan ini menyimpulkan bahwa BEP dapat tercapai setelah 10 bulan 20 hari dikarenakan BEP dapat selesai waktunya lebih cepat dari pembayaran cicilan di bank, maka proyek tesrsebut dapat direkomendasikan untuk dikerjakan.
\end{abstract}

Kata kunci : NPV, IRR, BEP

\section{PENDAHULUAN}

Kalimantan Timur merupakan salah satu propinsi Indonesia yang memiliki data konsumsi daging sapi cenderung meningkat per tahunnya. Dilihat dari total konsumsi masyarakat per kabupaten/kota, propinsi Kalimantan Timur, konsumsi daging sapi masyarakat naik dari 10.400 ton tahun 2014 menjadi 10.852 ton pada tahun 2016. Jika dibandingkan konsumsi daging sapi dengan produksi daging sapi yang disediakan, masih terdapat kebutuhan daging sapi yang belum terpenuhi. Produksi daging sapi di Kalimantan Timur tahun 2014 sebesar 8.700 ton meningkat pada tahun 2015 sebesar 9.129 ton (Sumber Direktorat Jenderal Peternakan, 2014-2018). Angka tersebut cukup signifikan per tahunnya dan sekaligus merupakan peluang bisnis dalam penjualan daging khususnya daging sapi. Dilihat dari konsumsi dan produksi daging sapi di Kutai Timur, konsumsi daging sapi di Kutai Timur tahun 2014 sebesar 536,8 ton. Sedangkan produksi daging sapi di Kutai Timur tahun 2014 sebesar 563,2 ton. (Sumber Dinas Peternakan Propinsi Kalimantan Timur, 2014). 
Daging sapi banyak di gunakan sebagai salah satu olahan makanan, yaitu pembuatan bakso. Menurut Astawan (2008), bahwa bakso adalah produk olahan daging giling yang dicampur dengan tepung dan bumbu-bumbu serta bahan lain yang dihaluskan, kemudian dibentuk bulatan - bulatan dan kemudian direbus hingga matang. Dengan menjalankan kegiatan usaha bakso daging sapi ini bisa mendatangkan keuntungan yang banyak. Tingginya pencinta bakso di kota-kota besar dan daerah semakin menghasilkan peluang terbuka lebar. Bisnis bakso tidak pernah mati, bahkan semakin berkembang menjadi bisnis yang besar dan banyak pelakunya. Bakso daging sapi adalah salah satu olahan makanan yang digemari selain jenis bakso lainnya. Alasan mengapa bakso daging sapi banyak digemari adalah rasa gurih, kenyal, memiliki serat yang renyah, serta aroma dari daging sapi yang nikmat mampu menggugah selera.

Meskipun penjualan bakso daging sapi di Sangatta meningkat, namun belum terdapat toko daging yang menjual daging sapi secara bersih, hiegienis, termasuk juga usaha penggilingan daging untuk keperluan pembuatan bakso daging sapi. Penjualan di Sangatta selama ini berada di pasar-pasar tradisional, seperti : pasar Sangatta Lama, pasar Induk, pasar Town Hall. Sedangkan penggilingan baso daging sapi hanya ada di pasar Sangatta Lama dan pasar Induk.

Penduduk Sangatta yang ingin membuat bakso, atau pedagang di warung-warung termasuk pedagang bakso keliling setiap pagi datang ke pasar Sangatta Lama atau pasar Induk untuk menggiling daging sapi yang dibelinya. Ongkos jasa penggilingan daging sapi per kilo gram nya berkisar Rp. 7.000 sampai dengan Rp 9.000. Sedangkan ongkos jasa penggilingan ditambah dengan adonan pembuatan daging bakso (sudah ditambah tepung dan bumbu paling mahal Rp. 20.000 per kilogramnya.

Proses penggilingan sapi masih manual. Daging sudah dipotong-potong, tanpa dicuci, langsung dari pedagang daging sapi di pasar di giling ke dalam mesin penggilingan daging. Tergantung permintaan konsumen, jika hanya ingin digiling, maka setelah proses penggilingan, dimasukkan ke dalam kresek kantong plastik dapat di bawa pulang. Jika ingin dibuat bakso, maka pedagang yang ada di pasar akan mencampurkan dengan bahan lain, seperti tepung kanji, bumbu masak seperti royco atau masako dan di campurkan bersama dengan daging sapi yang dudah digiling di campur dengan es batu sampai adonan menyatu. Proses dilakukan secara manual dalam sebuah wadah besar, dicampur dan diaduk 
menggunakan tangan. Ruangan pengolahan juga becek karena es batu yang mencair di mana-mana sehingga terasa kotor dan tidak higienis.

Peneliti bermaksud membuat usaha toko daging yang higienis di Sangatta. Pemikiran ini bersumber dari belum adanya penjualan daging sapi beserta penggilingan daging sapi yang higienis di Sangatta. Tujuan pembuatan toko daging di atas, untuk pengembangan jangka pendek agar dapat memenuhi kebutuhan konsumsi daging sapi masyarakat Sangatta dan sekitarnya. Sedangkan tujuan jangka panjang, toko daging ini akan menangani pemesanan daging sapi dari kota lain seperti Bontang, Samarinda dan Balikpapan yang membutuhkan daging sapi sebagai salah satu sumber makanan penduduknya.

Toko daging sapi yang akan didirikan di Sangatta berlokasi di dekat (area) pasar Teluk Lingga. Pemilihan lokasi ini dengan alasan karena lokasinya dekat dengan pasar, kantor, sekolah, dan dekat dengan pemukiman. Produk yang diusulkan dalam penjualan daging sapi ini berbentuk potongan daging sapi dengan tulang, daging sapi tanpa tulang, daging sapi yang di potong-potong kecil atau digiling sesuai dengan kebutuhan pelanggan. Semua akan dikemas secara higienis.

Penjualan daging sapi dilakukan dalam sebuah ruangan yang bersih dengan AC dan tidak becek. Daging di tata dalam etalase kaca sehingga konsumen dapat melihat dan membeli daging sesuai kebutuhannya. Toko daging memiliki cool storage untuk penyimpanan daging sapi yang diatur suhunya dan akan diawasi seorang butcher (tukang daging) yang profesional dibantu dengan seorang tenaga penjualan. Motto toko daging yang akan di adakan adalah memberikan pelayanan lebih cepat, higienis, harga kompetitif dan produk daging yang sehat dan segar.

\section{KAJIAN TEORI}

Studi kelayakan bisnis merupakan gambaran kegiatan usaha yang direncanakan, sesuai dengan kondisi, potensi, serta peluang yang tersedia dari berbagai aspek. Studi kelayakan yang juga sering disebut dengan feasibility study merupakan bahan pertimbangan dalam mengambil suatu keputusan untuk menerima atau menolak dari suatu gagasan usaha/proyek yang direncanakan. Pengertian layak dalam penilaian studi kelayakan adalah kemungkinan dari gagasan usaha/proyek yang akan dilaksanakan memberikan manfaat (benefit), baik dalam arti finansial maupun dalam arti sosial benefit (Pusdiklat Industri, 2013:19). 
Aspek finansial merupakan suatu gambaran yang bertujuan untuk menilai kelayakan suatu usaha untuk dijalankan atau tidak dijalankan dengan melihat dari beberapa kriteria kelayakan. Analisis finansial adalah analisis dimana suatu proyek dilihat dari sudut yang bersifat individual artinya tidak perlu diperhatikan apakah efek atau dampak dalam perekonomian dalam lingkup yang lebih luas. Analisis finansial memperhatikan hasil total atau produktivitas maupun keuntungan yang didapat dari semua sumber yang dipakai dalam proyek untuk masyarakat atau perekonomian secara keseluruhan, tanpa melihat siapa yang menyediakan sumber tersebut dan siapa yang menerima hasil proyek tersebut (Kadariah, 2001:41).

Analisis finansial dan ekonomi hendaknya mencakup semua beban biaya, baik biaya investasi maupun total biaya produksi dan perbandingan dengan perkiraan hasil revenue (keuntungan) yang akan diperoleh. Berdasarkan perkiraan biaya dan penerimaan itu selanjutnya dianalisis berapa lama modal investasi akan kembali dan berapa besar nilai proyek atau usaha yang akan diperoleh pada akhir masa proyek atau usaha tersebut. Analisis tersebut digambarkan berdasarkan metode diskonto dan analisis sensitivitas untuk melihat apakah usaha tersebut layak dan relatif lebih menguntungkan untuk dikembangkan.

Nitisemino dan Burhan (2009:81), menyatakan bahwa ada dua faktor perting sebagai dasar perhitungan analisis finansial, yaitu : pertama, perhitungan nilai-nilai proyek berdasarkan pertimbangan faktor waktu atau faktor kemerosotan nilai; kedua, asumsi nilai satuan yang digunakan sebagai dasar perhitungan.

\section{NPV (Net Present Value)}

Net Present Value atau sering disingkat dengan NPV adalah selisih antara nilai sekarang dari arus kas yang masuk dengan nilai sekarang dari arus kas yang keluar pada periode waktu tertentu. NPV atau Net Present Value ini mengestimasikan nilai sekarang pada suatu proyek, aset ataupun investasi berdasarkan arus kas masuk yang diharapkan pada masa depan dan arus kas keluar yang disesuaikan dengan suku bunga dan harga pembelian awal. Net Pressent Value menggunakan harga pembelian awal dan nilai waktu uang (time value of money) untuk menghitung nilai suatu aset. Dengan demikian, dapat dikatakan bahwa NPV adalah Nilai Sekarang dari Aset yang dikurangi dengan harga pembelian awal. 
NPV atau Net Present Value ini banyak digunakan dalam penganggaran modal untuk menganalisa profitabilitas dari sebuah proyek ataupun proyeksi investasi. Para pemilik modal ataupun manajemen perusahaan dapat menggunakan perhitungan NPV ini untuk mengevaluasi apakah akan berinvestasi atau tidak berinvestasi pada suatu proyek baru ataupun investasi pada pembelian aset baru. Dalam bahasa Indonesia, Net Present Value atau NPV ini disebut juga dengan "Nilai Bersih Sekarang” atau "Nilai Bersih Saat Ini”.

Pengertian NPV (Net Present Value) menurut R. Agus Sartono (2010:195), Net Present Value adalah Selisih antara present value aliran kas bersih atau sering disebut juga dengan procceed dengan present value Investasi. Pengertian NPV (Net Present Value) menurut Syafaruddin Alwi (2001,163), Net Present Value merupakan model yang memperhitungkan pola cash flows keseluruhan dari suatu investasi, dalam kaitannya dengan waktu, berdasarkan Discount Rate tertentu.

\section{IRR (Internal Rate of Return)}

IRR adalah singkatan dari Internal Rate of Return yang menjadi salah satu acuan penghitungan efisiensi dari sebuah investasi. Secara sederhana, penghitungan IRR dapat menjadi dasar apakah sebuah investasi layak dilakukan atau tidak. Sebuah investasi yang dianggap layak jalan harus memenuhi kriteria nilai IRR lebih tinggi ketimbang minimum acceptable rate of return atau minimum attractive rate of return. Internal Rate of Return (IRR) sebetulnya adalah metode untuk menghitung tingkat bunga (discount rate) yang membuat nilai saat ini dari seluruh perkiraan arus kas masuk sama dengan nilai sekarang dari ekspektasi arus kas yang keluar (Hazen, 2009). Prinsipnya, IRR adalah rangkaian penghitungan yang membuat nilai NPV (Net Present Value) menjadi nol.

\section{BEP (Break Event Point)}

BEP atau Break Even Point adalah titik dimana pendapatan sama dengan modal yang dikeluarkan, tidak terjadi kerugian atau keuntungan. Total keuntungan dan kerugian ada pada posisi 0 titik break even point yang artinya pada titik ini perusahaan tidak mengalami kerugian atau mendapat keuntungan. Hal tersebut dapat terjadi bila perusahaan dalam operasinya menggunakan biaya tetap, dan volume penjualan hanya cukup untuk menutup biaya tetap dan biaya variabel. Apabila penjualan hanya cukup untuk menutup biaya variabel 
dan sebagian biaya tetap, maka perusahaan menderita kerugian. Sebaliknya akan memperoleh memperoleh keuntungan, bila penjualan melebihi biaya variabel dan biaya tetap yang harus di keluarkan.

\section{METODE PENELITIAN}

Metode penelitian yang digunakan adalah pendekatan kuantitatif. Penelitian ini sepenuhnya memanfaatkan data sekunder sebagai basis data utama dalam proses analisis. Data sekunder yang digunakan adalah data keuangan yang berhubungan dengan pendirian usaha jasa penjualan dan penggilingan daging tahun 2020 .

\section{Alat Analisis}

Suatu usaha yang telah diputuskan layak untuk dilaksanakan berdasarkan perhitungan dan analisis serta hasil evaluasi (IRR, NPV, Net B/C, PP), ternyata di dalamnya tidak tertutup kemungkinan adanya kesalahan-kesalahan dalam perhitungan. Hal tersebut dapat dikarenakan ketidakstabilan harga faktor-faktor produksi maupun harga produk itu sendiri. Berdasarkan kemungkinan-kemungkinan tersebut berarti harus diadakan analisa kembali untuk meninjau dan mengetahui sejauh mana dapat dilakukan penyesuaian-penyesuaian sehubungan dengan adanya perubahan-perubahan tersebut. Tindakan menganalisa kembali ini dinamakan analisis sensitivitas (sensitivity analysis).

Analisis proyek banyak memerlukan ramalan (forcasting), maka perhitunganperhitungan biaya konstruksi dapat dipengaruhi keadaan cuaca, umur berguna (useful life), investasi dapat lebih pendek karena adanya penemuan-penemuan, permintaan terhadap jasa angkutan dapat berubah karena adanya perubahan-perubahan yang tidak diketahui sebelumnya dalam pola pembangunan ekonomi dan masih banyak faktor-faktor lain yang dapat membuat ramalan kurang tepat (Kadariah, 2001:19).

Hasil analisa kepekaan menghasilkan perkiraan jumlah permintaan yang sifatnya optimistis, pesimistis, dan realistis. Sebagai contoh apabila survei dilapangan diperoleh gambaran bahwa permintaan dipengaruhi perubahan harga sedangkan harga meningkat ratarata $2 \%$ pertahun, maka proyeksi permintaan produk dimasa yang akan datang dapat ditentukan beberapa asumsi penggunaannya, misalkan selama 5 sampai 10 tahun yang akan datang tidak terjadi kenaikan harga, atau selama 5 sampai 10 tahun yang akan datang terjadi kenaikan harga rata-rata 2\% (Swastawati, 2011:35). 
Analisis sensitivitas dapat dikatakan sebagai suatu kegiatan menganalisis kembali suatu proyek untuk melihat apakah yang akan terjadi pada proyek tersebut bila suatu proyek tidak berjalan sesuai rencana. Analisis sensitivitas ini mencoba melihat suatu realitas proyek yang didasarkan pada kenyataan bahwa proyeksi dari suatu rencana proyek sangat dipengaruhi oleh unsur-unsur ketidakpastian mengenai apa yang terjadi di masa mendatang (Gittinger, 1986:60). Biaya dan penerimaan dalam suatu proyek, jumlahnya mempengaruhi besarnya IRR, NPV, Net B/C Rasio dan PP. Perubahan kriteria-kriteria tersebut dapat terjadi karena adanya perubahan dalam dasar-dasar perhitungan biaya dan manfaat.

Menurut Syarif (2003:157), studi kelayakan terhadap aspek keuangan perlu menganalisis bagaimana prakiraan aliran kas yang akan terjadi. Beberapa kriteria investasi yang digunakan untuk menentukan diterima atau tidaknya sesuatu usulan usaha sebagai berikut :

a. Net Present Value (NPV) atau nilai bersih sekarang merupakan perbandingan antara PV kas bersih dengan PV Investasi selama umur investasi.

b. IRR (Internal Rate of Return) merupakan tingkat suku bunga yang dapat membuat besarnya nilai NPV dari suatu usaha sama dengan nol atau yang dapat membuat nilai Net B/C Ratio sama dengan satu dalam jangka waktu tertentu.

c. BEP (Break Even Point) yaitu titik pulang balik dimana menyatakan bahwa Total Revenue (Pendapatan) sama dengan Total Cost (Pengeluaran)

\section{HASIL DAN PEMBAHASAN}

\section{Gambaran Umum Objek Penelitian}

Toko penjualan dan penggilingan daging yang akan didirikan di lokasi area pasar Teluk Lingga, merupakan daerah pemukiman yang terpadat penduduknya di Sangatta. Penentuan lokasi pendirian usaha penjualan dan penggilingan daging sapi ini juga dikarenakan alasan belum terdapatnya usaha penjualan dan penggilingan daging sapi di daerah tersebut. Usaha penjualan dan penggilingan daging ini berasal dari ide usaha penggilingan daging sapi yang ada di pasar Induk Sangatta. Namun kenyataannya, banyak konsumen yang mengeluh karena kurang higienis usaha penggilingan di pasar Induk Sangatta. 
Toko usaha penjualan dan penggilingan daging sapi yang akan didirikan ini nantinya memiliki moto lebih baik, lebih bersih, kompetitif dan higienies. Toko usaha ini akan menggunakan mesin pemotongan daging dan penggilingan daging sapi secara otomatis, dimana daging sudah dicuci bersih dimasukkan ke dalam mesin langsung menjadi bakso sesuai ukuran yang diminta oleh konsumen. Pengambilan daging dari rumah potong hewan pun akan dilakukan secara higienis dan di bawa ke toko menggunakan mobil yang sudah direnovasi sehingga daging tidak mengalami kerusakan. Demikian pula daging yang belum dijual akan disimpan dalam cool storage yang akan menyimpan daging secara bersih dan aman.

Toko usaha penjualan dan penggilingan daging yang akan didirikan modelnya seperti di bawah ini. Dapat dilihat pada gambar 4.1.

Gambar 4.1

Toko Usaha Penjualan dan Penggilingan Daging Sapi

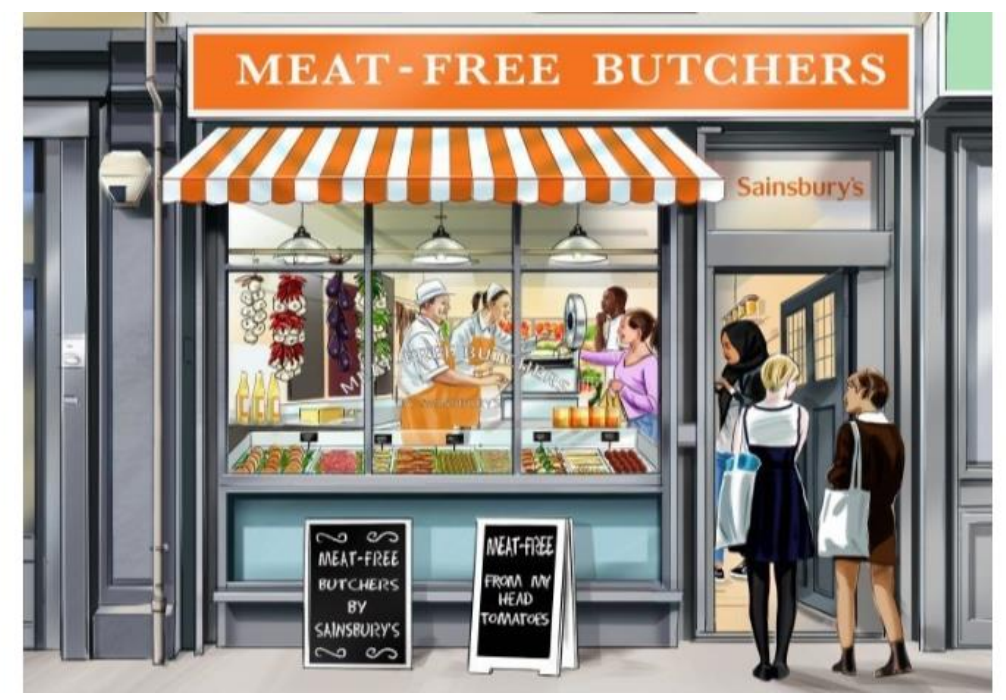

Sumber : dikutip dari dokumen meat shop, 2020

Luas bangunan toko adalah 8 × 12 meter. Ruangan dibagi dua bagian, dimana bagian pertama untuk penjualan daging dan bagian kedua untuk penggilingan daging sapi. Terdapat ruangan tunggu terdiri dari meja dan kursi bagi konsumen yang menunggu penggilingan daging. Ruangan juga memiliki AC sehingga terasa sejuk dan konsumen akan merasa nyaman berbelanja di sana.

Karyawan yang bekerja sebanyak 4 (empat) orang, terdiri dari kepala toko (merangkap tukang potong daging), tukang potong, kasir dan asisten toko yang bertanggung jawab 
terhadap kebersihan. Bekerja dari jam 07.00 - 17.00 wita. Masuk kerja dari hari Senin sampai dengan Minggu. Pembayaran gaji disesuaikan dengan aturan ketenagakerjaan yaitu satu minggu kerja 40 jam. Selebihnya dikenakan lembur. Hari besar seperti hari Raya keagamaan (Idul Fitri, Idul Adha, Natal dan Tahun Baru) toko tutup.

Toko usaha penjualan dan penggilingan daging sapi ini juga menerima pesanan secara online dan akan diantar menggunakan mobil yang dimiliki oleh toko pada jam pengantaran yang sudah ditentukan. Waktunya fleksibel tergantung pesanan konsumen. Harga penjualan daging kompetitif dengan penjual daging lainnya yaitu seharga Rp 130.000,- perkilogramnya. Selain itu daging juga dikemas dengan berbagai ukuran yang dipajang dalam freezer showcase sehingga memudahkan dan mempercepat konsumen berbelanja. Toko usaha penjualan dan penggilingan daging sapi ini menerima pesanan untuk kebutuhan catering, pesta perkawinan ataupun acara tertentu.

\section{Penyajian Data penelitian}

\section{Penjualan Daging Sapi}

Daging sapi yang akan dijual ditata dengan rapih di dalam freezer showcase dalam berbagai ukuran. Daging di kemas dalam mika yang sudah dibungkus dengan plastik transparan, sehingga konsumen lebih mudah memilih sesuai dengan kebutuhan dan kemampuannya.

Selain memiliki freezer showcase seperti di atas, toko usaha penjualan dan penggilingan daging memiliki model lain yaitu seperti di bawah ini. Keduanya memiliki fungsi untuk memamerkan daging yang akan di jual dengan rapi dan bersih. Daging sapi utuh yang baru datang akan disimpan dalam cool storage yang muat sampai dengan lebih dari 100 kilogram. Daging sapi yang dimasukkan dalam cool storage akan membeku demi menghindari kebusukan.

\section{Penggilingan Daging Sapi}

Untuk proses penggilingan dan pembuatan bakso yang banyak dibutuhkan konsumen, toko usaha penjualan dan penggilingan daging sapi ini menggunakan dua mesin yang higienis, yaitu pertama mesin penggilingan daging dan msein pembuatan bakso secara otomatis. 


\section{Analisis Data}

Analisis data penelitian ini ditinjau dari beberapa aspek, yaitu :

\section{Aspek Pemasaran}

Toko penjualan dan penggilingan daging sapi yang akan dibuka berada di sekitar daerah pasar Teluk Lingga. Toko penjualan dan penggilingan daging sapi akan menempati bangunan ruko satu lantai berukuran $8 \times 12 \mathrm{~m}$. Lokasi dekat pasar Teluk Lingga sangat strategis karena pasar tidak pernah sepi dari pembeli. Toko tersebut selain menyediakan penjualan daging sapi, juga memberikan jasa penggilingan daging sapi (bisa dalam bentuk bakso).

Harga jual daging sapi saat ini per kilogram Rp. 130.000,- Harga giling daging sapi per kilogram Rp 12.500,- Sedangkan harga giling daging sapi bersama bahan lainnya seperti bumbu dan tepung untuk pembuatan bakso sapi per kilogram nya adalah Rp 40.000,Penjualan daging sapi diperkirakan per harinya mencapai rata-rata $60 \mathrm{~kg}$ daging sapi, sementara pembuatan bakso daging sapi per harinya diperkirakan rata-rata mencapai 30 kilogram. Perkiraan ini berdasarkan asumsi : pertama, toko penjualan daging sapi ini masih baru dibuka; kedua, mengambil data penjualan separuh dari penjualan daging sapi di pasar Induk Sangatta.

\section{Aspek Teknis}

Berdasarkan hasil observasi yang diadakan pada usaha jasa penjualan dan penggilingan daging sapi di pasar Induk Sangatta, ditambah dengan pemikiran penulis kebutuhan penjualan dan penggilingan daging sapi yang up to date, maka di dapat perhitungan investasi sesuai dengan keinginan dari pemilik toko penjualan dan penggilingan daging sapi sebagai berikut : 
Tabel 4.1

Investasi Toko Penjualan dan Penggilingan Daging Sapi

\begin{tabular}{|c|c|}
\hline Kebutuhan Investasi & Nilai \\
\hline 1. Sewa Ruko (dua tahun) & 100.000 .000 \\
\hline 2. Cool Storage & 4.638 .000 \\
\hline 3. Etalase kaca (dua buah) & 33.000 .000 \\
\hline 4. Meja potong daging & 3.000 .000 \\
\hline 5. Meja tempat penggilingan daging & 1.000 .000 \\
\hline 6. Meja dan kursi kasir & 4.000 .000 \\
\hline 7. AC (dua buah) & 10.000 .000 \\
\hline 8. Peralatan potong (pisau, butcher, talenan) & 2.000 .000 \\
\hline 9. Mesin pemotong daging & 3.500 .000 \\
\hline 10. Penggilingan daging & 3.977 .000 \\
\hline 11. Penggilingan bakso otomatis & 12.885 .000 \\
\hline 12. Meja dapur +cuci stenliss & 2.000 .000 \\
\hline 13. Mobil Daihatsu Pick Up + repair & 200.000 .000 \\
\hline 14. Timbangan digital & 2.865 .000 \\
\hline 15. Mesin kasir & 3.425 .000 \\
\hline 14. Perlengkapan lainnya & 8.710 .000 \\
\hline & 395.000 .000 \\
\hline Modal Kerja & 20.000 .000 \\
\hline Jumlah & 415.000 .000 \\
\hline
\end{tabular}

Sumber : data diolah penulis, 2020

Investasi yang dibutuhkan yaitu sebesar Rp 415.000.000,- dengan rincian seperti di atas. Investasi yang dibutuhkan sebesar Rp 395.000.000,-. Modal kerja yang dibutuhkan sebesar Rp. 20.000,000,- . Modal kerja digunakan untuk membeli satu ekor sapi untuk dijual kembali. 


\section{Sumber Modal}

Investasi untuk membiayai pendirian toko penjualan dan penggilingan daging sapi sebesar Rp. 415.000.000,- sebesar Rp 200.000.000,- dibiayai sumber dana pribadi dan sisanya sebesar Rp. 215.000.000 merupakan kredit bank dengan tingkat bunga sebesar $18 \%$ per tahun dan dimajemukkan setiap tahun selama 5 (lima) tahun.

\section{Biaya Operasi dan Pemeliharaan}

Tabel 4.2

Rekapitulasi Biaya Tetap dan Biaya Variabel Pendirian Toko Penjualan dan Penggilingan Daging Sapi (Rp 000)

\begin{tabular}{|c|c|c|c|c|c|}
\hline \multirow[t]{2}{*}{ Jenis Biaya } & \multicolumn{5}{|c|}{ Tahun } \\
\hline & 1 & 2 & 3 & 4 & 5 \\
\hline \multicolumn{6}{|l|}{ A. Biaya Tetap } \\
\hline Gaji Karyawan & 135.600 & 162.720 & 195.264 & 234.317 & 281.180 \\
\hline Penyusutan & 42.000 & 42.000 & 42.000 & 42.000 & 42.000 \\
\hline Biaya Umum & 12.000 & 12.000 & 12.000 & 12.000 & 12.000 \\
\hline Pemeliharaan & 12.000 & 12.000 & 12.000 & 12.000 & 12.000 \\
\hline Listrik & 12.000 & 12.000 & 12.000 & 12.000 & 12.000 \\
\hline Air & 9.000 & 9.000 & 9.000 & 9.000 & 9.000 \\
\hline Promosi & 1.000 & 1.000 & 1.000 & 1.000 & 1.000 \\
\hline THR & 11.300 & 13.560 & 16.272 & 19.526 & 23.432 \\
\hline B. Biaya Variabel & & & & & \\
\hline Bahan bakar & 2.400 & 2.400 & 2.400 & 2.400 & 2.400 \\
\hline $\begin{array}{l}\text { Bahan lainnya } \\
\text { (plastik, mika, }\end{array}$ & 3.000 & 3.000 & 3.000 & 3.000 & 3.000 \\
\hline $\begin{array}{l}\text { kresek, dll) } \\
\text { Biaya potong } \\
\text { sapi }\end{array}$ & 36.000 & 36.000 & 36.000 & 36.000 & 36.000 \\
\hline $\begin{array}{l}\text { Biaya angkut } \\
\text { sapi ke RPH }\end{array}$ & 45.000 & 45.000 & 45.000 & 45.000 & 45.000 \\
\hline $\begin{array}{l}\text { Biaya antar ke } \\
\text { toko }\end{array}$ & 12.000 & 12.000 & 12.000 & 12.000 & 12.000 \\
\hline Biaya lain-lain & 10.000 & 10.000 & 10.000 & 10.000 & 10.000 \\
\hline Jumlah & 343.300 & 372.680 & 407.936 & 450.243 & 501.012 \\
\hline
\end{tabular}

Sumber : data diolah penulis, 2020 
Rekapitulasi pendirian toko penjualan dan penggilingan daging sapi terbagi menjadi dua yaitu biaya tetap dan biaya variabel. Biaya tetap terdiri dari gaji karyawan, penyusutan, biaya umum, pemeliharaan, listrik, air, promosi dan THR. Sedangkan biaya variabel terdiri dari bahan bakar, bahan lainnya, biaya potong sapi, biaya angkut sapi ke RPH, biaya antar ke toko dan biaya lainnya. Total biaya tetap dan variabel mengalami kenaikan tiap tahunnya.

\section{Investasi Dengan Kredit Bank}

Pemilik rumah potong hewan membutuhkan kredit bank untuk pendirian toko penjualan dan penggilingan daging termasuk pembelian peralatan yang dibutuhkan. Jumlah pinjaman yang diajukan sebesar Rp 215.000.000,- dan dicicil selama lima tahun dengan bunga sebesar $18 \%$. Berikut di bawah ini di sajikan rincian pinjaman dan nilai hutang yang harus dikembalikan ke pihak bank.

Tabel 4.3

Jumlah Pengembalian Pokok Pinjaman dan

Bunga Pinjaman

(Rp 000)

\begin{tabular}{|c|c|r|r|r|r|}
\hline Tahun & Cicilan & $\begin{array}{c}\text { Bunga 18 } \\
\%\end{array}$ & $\begin{array}{c}\text { Pengembalian } \\
\text { Pinjaman }\end{array}$ & $\begin{array}{c}\text { Jumlah } \\
\text { Pengembalian }\end{array}$ & Sisa Kredit \\
\hline 0 & & & & & 215.000 \\
\hline 1 & 68.739 & 38.700 & 30.039 & 30.039 & 184.961 \\
\hline 2 & 68.739 & 33.293 & 35.446 & 65.485 & 149.515 \\
\hline 3 & 68.739 & 26.913 & 41.826 & 107.311 & 107.689 \\
\hline 4 & 68.739 & 19.384 & 49.355 & 156.666 & 58.334 \\
\hline 5 & 68.739 & 10.500 & 58.239 & 214.905 & \\
\hline
\end{tabular}

Sumber : data diolah penulis, 2020

\section{Net Present Value}

Pendapatan kotor toko penjualan dan penggilingan daging meningkat tiap tahunnya. Pendapatan setiap tahunnya didapat dari pendapatan hasil penjualan daging sapi, hasil penggilingan daging dan pendapatan lainnya seperti penjualan kulit, kepala sapi. Prediksi per hari penjualan daging sapi rata-rata yang laku adalah sebanyak 100 kilogram sehingga pada tahun pertama prediksi penjualan sapi sebesar Rp. 4,680.000.000,-. Sedangkan pendapatan 
dari jasa penggilingan daging sapi rata-rata sebesar Rp. 288.000.000,- dan pendapatan lainnya sebesar Rp 180.000.000,- sehingga pada tahun pertama di dapat pendapatan sebesar Rp 5.148.000.000,-. Kenaikan pendapatan penjualan dan penggilingan daging sapi rata-rata pertahunnya diprediksi sebesar sepuluh persen per tahunnya.

Total cost merupakan penjumlahan dari biaya operasi (operating cost) di tambah dengan kredit bank yang terdiri dari cicilan pokok hutang ditambah bunga bank ditambah pajak sebesar 15 persen. Discount Factor (DF) dalam perhitungan Net Presen Value ini sebesar $18 \%$. Net Present Value selama lima tahun adalah sebesar Rp 7.181.879.315,-

Tabel 4.4

Net Present Value

Penjualan dan penggilingan Daging Sapi

\begin{tabular}{|c|r|r|r|}
\hline $\begin{array}{c}\text { Tahun } \\
\text { ke }\end{array}$ & Penjualan Kotor & Total Biaya & $\begin{array}{c}\text { Present Value DF } \\
18 \%\end{array}$ \\
\hline 0 & 2.088 .000 .000 & 200.000 .000 & $(200.000 .000)$ \\
1 & 2.448 .000 .000 & 412.039 .000 & 1.210 .881 .823 \\
2 & 2.574 .000 .000 & 441.419 .000 & 1.449 .754 .773 \\
3 & 2.700 .000 .000 & 476.675 .000 & 1.515 .317 .313 \\
4 & 2.826 .000 .000 & 518.982 .000 & 1.575 .785 .505 \\
5 & Jumlah & 569.751 .000 & 1.630 .139 .903 \\
& & & 7.181 .879 .315 \\
& & & \\
\hline
\end{tabular}

Sumber : data diolah penulis, 2020

\section{IRR (Internal rate of Return)}

Dilihat dari nilai IRR nya yaitu tingkat discount rate yang menghasilkan net present value sama dengan nol. Apabila perhitungan IRR $>0$, maka usaha tersebut dikatakan feasible (layak).

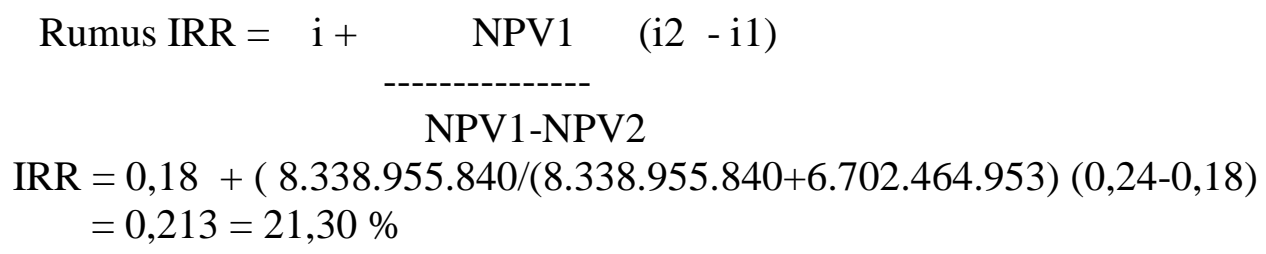

Net $B / C=50,2$ 
Tabel 4.5

Perhitungan IRR dan Net B/C Ratio

Toko Penjualan dan Penggilingan daging Sapi

\begin{tabular}{|c|r|r|r|r|r|}
\hline Tahun & \multicolumn{1}{|l|}{ Net Benefit } & DF $18 \%$ & \multicolumn{1}{c|}{ Present Value } & \multicolumn{1}{c|}{ DF $24 \%$} & \multicolumn{1}{c|}{ Present Kredit } \\
\hline 0 & $(200.000 .000)$ & 1,000 & $(200.000 .000)$ & 1,000 & $(200.000 .000)$ \\
\hline 1 & 1.452 .246 .250 & 0,850 & 1.234 .409 .313 & 0,808 & 997.834 .768 \\
\hline 2 & 1.850 .045 .400 & 0,850 & 1.572 .538 .590 & 0,808 & 1.271 .161 .569 \\
\hline 3 & 2.048 .946 .250 & 0,850 & 1.741 .604 .313 & 0,808 & 1.407 .825 .846 \\
\hline 4 & 2.247 .846 .250 & 0,850 & 1.910 .669 .313 & 0,808 & 1.544 .489 .539 \\
\hline 5 & 2.446 .746 .250 & 0,850 & 2.079 .734 .313 & 0,808 & 1.681 .153 .232 \\
\hline & 10.045 .830 .400 & & 8.338 .955 .840 & & 6.702 .464 .953 \\
\hline
\end{tabular}

Sumber : data diolah penulis, 2020

\section{BEP (Break Even Point)}

Mencari perhitungan break even point (titik pulang balik) menggunakan rumus :

$$
\begin{aligned}
\mathrm{BEP}= & \mathrm{T} \mathrm{p}-1+\frac{\mathrm{TC} \mathrm{i}-\mathrm{B} \mathrm{i} \mathrm{cp}-1}{\mathrm{Bi}} \\
& =4-(3.921 .604 .790-.3 .826 .577 .400) / 193.374 .090 \\
& =10 \text { bulan } 20 \text { hari }
\end{aligned}
$$

Tabel 4.6

Perhitungan Break Even Point

Penjualan dan Penggilingan Daging Sapi

\begin{tabular}{|c|c|c|c|c|c|}
\hline Tahun & Total Cost & Benefit & $\begin{array}{c}\text { DF 18 } \\
\%\end{array}$ & $\begin{array}{c}\text { Total Cost .DF 18 } \\
\%\end{array}$ & $\begin{array}{c}\text { Benefit .DF } \\
18 \%\end{array}$ \\
\hline 0 & 200.000 .000 & & 1,000 & 200.000 .000 & - \\
\hline 1 & 594.694 .150 & 2.088 .000 .000 & 0,850 & 505.490 .028 & 1.774 .800 .000 \\
\hline 2 & 673.667 .150 & 2.448 .000 .000 & 0,850 & 572.617 .078 & 2.080 .800 .000 \\
\hline 3 & 722.534 .750 & 2.574 .000 .000 & 0,850 & 614.154 .538 & 2.187 .900 .000 \\
\hline 4 & 777.395 .700 & 2.700 .000 .000 & 0,850 & 660.786 .345 & 2.295 .000 .000 \\
\hline 5 & 839.449 .350 & 2.826 .000 .000 & 0,850 & 713.531 .948 & 2.402 .100 .000 \\
\hline & & & & 3.266 .579 .935 & 10.740 .600 .000 \\
\hline
\end{tabular}

Sumber : data diolah penulis 


\section{Pembahasan}

Berdasarkan analisis data yang dilakukan dalam penelitian ini, dilihat dari aspek pemasaran, yaitu adanya peluang dalam usaha penjualan dan penggilingan daging sapi sehingga menghasilkan keuntungan yang cukup baik nilainya, yaitu rata-rata setiap bulannya dapat mencapai diatas Rp.170 juta. Di targetkan dalam satu bulan dapat menjual 15 ekor sapi. Pendapatan selain menjual daging sapi, didapat dari jasa penggilingan daging sapi dan pendapatan lainnya. Pendapatan lainnya yang dihasilkan dan tidak kalah menguntungkan adalah kulit sapi yang tidak diinginkan konsumen dapat dijual tersendiri sehingga dapat menambah keuntungan penjualan.

Dilihat dari aspek teknis, pendirian toko usaha penjualan dan penggilingan daging sapi membutuhkan biaya investasi yang cukup besar (di luar dari investasi tanah) yaitu sebesar Rp. 415 juta dan dana modal pribadi sebesar Rp 200 juta ditambah dengan dana dari kredit bank sebesar Rp 215 juta. Hutang bank dicicil selama lima tahun dengan bunga sebesar $18 \%$ per tahunnya.

Nilai present value yang di dapat selama lima tahun dalam usaha penjualan dan penggilingan daging sapi sebesar Rp. $\quad 7.181 .879 .315$,- Sedangkan Dilihat dari nilai IRR nya yaitu tingkat discount rate yang menghasilkan net present value sama dengan nol. Apabila perhitungan IRR > 0, maka usaha tersebut dikatakan feasible (layak).

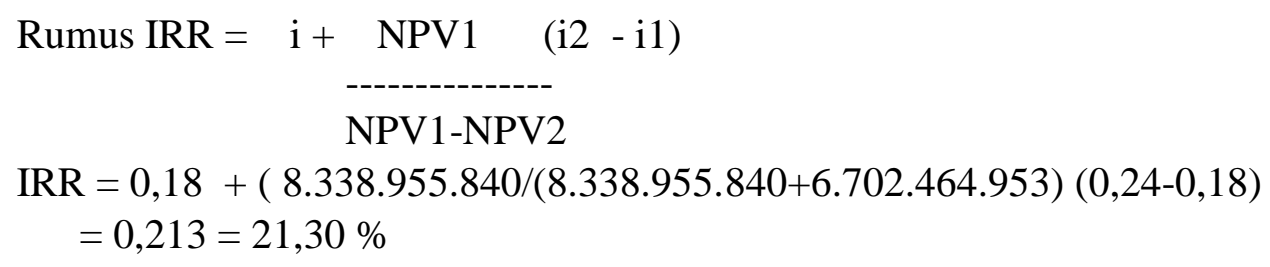

Jika nilai Net B/C lebih besar dari 1 (satu) berarti gagasan/usaha proyek tersebut layak untuk dikerjakan.

Dilihat dari titik pulang balik (break even point), yaitu titik keseimbangan antara total penerimaan dengan total pengeluaran atau $\mathrm{TR}=\mathrm{TC}$ didapat hasil sebagai berikut

Mencari perhitungan break even point (titik pulang balik) menggunakan rumus :

$$
\mathrm{BEP}=\mathrm{T} \mathrm{p}-1+\frac{\mathrm{TC} i-\mathrm{B} \mathrm{icp}-1}{\mathrm{Bi}}
$$




$$
\begin{aligned}
& =4+((3.266 .579 .935-10.740 .600 .000) / 2.402 .100 .000) \\
& =-3,111452506 \times 12 \text { bulan }=10 \text { bulan } 20 \text { hari }
\end{aligned}
$$

\section{PENUTUP}

\section{Kesimpulan}

Berdasarkan hasil analisis dan pembahasan yang telah dikemukakan pada bab sebelumnya dalam penelitian ini, dapat ditarik kesimpulan :

1. NPV (Net Present Value) yang dapat dicapai selama lima tahun adalah sebesar Rp. 7.181.879.315,- Keuntungan ini sangat baik dengan memberikan nilai positif yang cukup tinggi, sehingga usaha proyek ini baik untuk dikerjakan.

2. IRR sebesar $21,30 \%$ dan Net $B / C=50,2$. Oleh karena nilai Net $B / C>1$, maka memberikan arti bahwa gagasan/usaha proyek tersebut layak untuk dikerjakan.

3. Studi kelayakan ini menyimpulkan bahwa BEP dapat tercapai setelah 10 bulan 20 hari dikarenakan BEP dapat selesai waktunya lebih cepat dari pembayaran cicilan di bank, maka proyek tesrsebut dapat direkomendasikan untuk dikerjakan.

\section{Saran-saran}

1. Di karenakan usaha pendirian penjualan dan penggilingan daging sapi layak didirikan dan memiliki NPV yang sangat baik yaitu sebesar Rp 7.181.879.315, disarankan memasuki tahun ketiga dapat membangun ruko di daerah pasar Teluk Lingga atau membeli ruko yang selama ini disewa.

2. Perlu dipikirkan untuk memperluas pasar dengan menjalin hubungan baik dengan rumah makan, catering atau pedagangg daging sapi online yang ada di Sangatta.

3. Perlu dipikirkan perluasan usaha disesuaikan keinginan pasar dengan membuka penjualan dan penggilingan daging selain daging sapi. Contoh daging ayam atau ikan

\section{DAFTAR PUSTAKA}

Arby, Syarif. 2003. Bank dan Lembaga Keuangan Non-Bank. Jakarta : Djambatan

Chen, et al. 2005. An empirical investigation of the relationship between intellectual capital and firm's market value and financial performance. Journal of Intellectual Capital, Vol 6, Issue 2. 
Goldman, A., and Hayiel Hino, (2005). Supermarkets vs. traditional retail stores: diagnosing the barriers to supermarkets" market share growth in an ethnic minority community. Journal of Retailing and Consumer Services. pp. 273-284.

Hsu, Jane Lu dan Chang, We-Hsein, 2003. The Role of Advertising Played in Brand Switching, Journal of American Academy of Business, Cambridge, ABI, INFORM Global pg 332

Istanto. Hery. 2015. Analisis Laporan Keuangan. Edisi 1. Yogyakarta: Center For Academic Publishing Services

Kadariah, 2001. Evaluasi Proyek : Analisis Ekonomis. Lembaga Penerbitan Fakultas Ekonomi Universitas Indonesia. Jakarta

Lawrie, RA. 2003. Ilmu Daging. Universitas Indonesia. Jakarta

Manual Kesmavet, 2009. Pedoman Pembinaan Kesmavet. Direktorat Bina Kesehatan Hewan Direktorat Jendral Peternakan. Departemen Pertanian,Jakarta.

Nitisemito, Alex S. dan M. Umar Burhan. 2009. Wawasan Studi Kelayakan dan Evaluasi Proyek. Edisi Revisi. Cetakan Kedua. Bumi Aksara. Jakarta.

Soeparno. 2015. Ilmu dan teknologi daging cetakan ke 8. Gadjah Mada University Press, Yogyakarta.

Swastawati. 2011. Pemanfaatan Hasil Perikanan sebagai Produk Bernilai Tambah (ValueAdded) dalam Upaya Penganekaragaman Pangan. Jurnal Teknologi dan Industri Pangan, Vol. XIV, No. 1, Th. 2011.

Wong. Carol A. 2007. The relationship between nursing leadership and patient outcomes: a systematic review. HSA University of Western Ontario. Londo 
